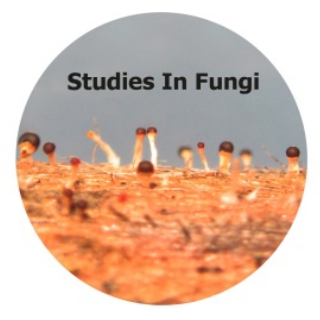

Studies in Fungi 4(1): 135-141 (2019) www.studiesinfungi.org ISSN 2465-4973

Article

Doi 10.5943/sif/4/1/16

\title{
Morphological description and new record of Panaeolus acuminatus (Agaricales) in Brazil
}

\author{
Xavier MD ${ }^{1}$, Silva-Filho AGS $^{2}$, Baseia IG $^{3}$ and Wartchow $\mathrm{F}^{4}$ \\ ${ }^{1}$ Curso de Graduação em Ciências Biológicas, Centro de Biociências, Universidade Federal do Rio Grande do \\ Norte, Av. Senador Salgado Filho, 3000, Campus Universitário, 59072-970, Natal, RN, Brazil \\ ${ }^{2}$ Programa de Pós-Graduação em Sistemática e Evolução, Centro de Biociências, Universidade Federal do Rio \\ Grande do Norte, Av. Senador Salgado Filho, 3000, Campus Universitário, 59072-970, Natal, RN, Brazil \\ ${ }^{3}$ Departamento de Botânica e Zoologia, Centro de Biociências, Universidade Federal do Rio Grande do Norte, Av. \\ Senador Salgado Filho, 3000, Campus Universitário, 59072-970, Natal, RN, Brazil \\ ${ }^{4}$ Departamento de Sistemática e Ecologia, Universidade Federal da Paraíba, Conj. Pres. Castelo Branco III, 58033- \\ 455, João Pessoa, PB, Brazil
}

Xavier MD, Silva-Filho AGS, Baseia IG, Wartchow F 2019 - Morphological description and new record of Panaeolus acuminatus (Agaricales) in Brazil. Studies in Fungi 4(1), 135-141, Doi $10.5943 / \mathrm{sif} / 4 / 1 / 16$

\begin{abstract}
Panaeolus acuminatus is described and illustrated based on fresh specimens collected from Northeast Brazil. This is the second known report of this species for the country, since it was already reported in 1930 by Rick. The species is characterized by the acuminate, pileus with hygrophanous surface, basidiospores measuring 11.5-16 × 5.5-11 $\mu \mathrm{m}$ and slender, non-capitate cheilocystidia. A full description accompanies photographs, line drawings and taxonomic discussion.
\end{abstract}

Key words - Agaricomycotina - Basidiomycota - biodiversity - dark-spored - Panaeoloideae Rick

\section{Introduction}

Species of Panaeolus (Fr.) Quél. are commonly recognized by their typically coprophilous or nitrophilous habitat, slender fruit-body with cartilaginous stipe and spotted gills originated by the maturation pattern of the basidiospores, in which they are distinctly smoky to dark brown, smooth, thick-walled, not discoloring in sulphuric acid and with a well-marked apical germ-pore (Watling \& Gregory 1987, Gerhardt 1996). This genus has worldwide distribution (Gerhardt 1996) but uncertain taxonomic position (Tóth et al. 2013).

In Brazil, Panaeolus and its allies genera (Panaeolina Maire, Copelandia Bres. and Anellaria P. Karst.) were poorly documented and the occasional records are known from South, Southeast, Midwest and Northeastern regions (Maia et al. 2015). Rick (1930) described $P$. lignicola Rick., and reported P. acuminatus (P. Kumm.) Quél., P. atro-sanguineus Henn, P. campanulatus (Bull.) Quél., P. solidipes (Peck) Sacc., P. semiovatus var. phalaenarum (Fr.) Ew. Gerhardt [as P. phalaenarum (Fr.) Quél.], P. fimicola (Fr.) Quél. and P. papilionaceus (Bull.) Quél., all from Rio Grande do Sul state. However some species need to be revised, since these names might correspond to misidentifications, synonyms or missed specimens (Silva-Filho et al. 2019). Stijve \& De Meijer (1993) recorded P. antillarum (Fr.) Dennis and P. cinctulus (Bolton) 
Sacc. from Paraná State. De Meijer (2001) in his first macrofungi checklist recorded $P$. papilionaceus (Bull.) Quél. from the state of Paraná. Sobestiansky (2005) recorded P. antillarum from Santa Catarina and $P$. cinctulus and P. papilionaceus from Rio Grande do Sul. De Meijer (2006) in his second checklist reported P. aff. reticulatus Overh. also from Paraná. More recently Panaeolus rickenii Hora was recorded from Mato Grosso do Sul, the first occurrence from Midwest (Bononi 2017). More recently, P. antillarum and P. papilionaceus were recorded again from Paraná, together with the description of $P$. sylvaticus Silva-Filho \& Cortez (Silva-Filho et al. 2019). Synonyms of other species also were reported from Brazil: Panaolus foenisecii (Pers.) J. Schröt. (currently a member of Panaeolina) by Stijve \& De Meijer (1993), and $P$. cambodginiensis Oláh \& R. Heim and P. aff. tropicalis Olah, (synonym of species of Copelandia) by De Meijer (2006). Recently, Panaeolus cyanescens (Berk. \& Broome) Sacc. synonym of Copelandia cyanescens (Berk. \& Broome) Singer was recorded from Paraná and Pernambuco (De Meijer 2001, Wartchow et al. 2010, Silva-Filho et al. 2018). From northeast Brazil, only Panaeolus antillarum is known (Alves \& Cavalcanti 1996, Melo et al. 2016).

Here we report the second occurrence of $P$. acuminatus from Brazil, and a revision of the Rick's exsicates of $P$. acuminatus and recent collection of $P$. rickenii from Brazil described as a variety of $P$. acuminatus. The species collected in northeast of Brazil and represents a new record in tropical region of America.

\section{Materials \& Methods}

The specimen was found on sandy soil in a grassland of an urban area (554'59.9" $\mathrm{S}$ and $35^{\circ} 13^{\prime} 02.9^{\prime \prime} \mathrm{W}$ ), in the municipality of Parnamirim, located in the metropolitan region of Natal, Rio Grande do Norte (Fig. 1). Methods for analysis and description of agarics were made following Singer (1986) and macro- and microstructures were described according to terminology used by Largent (1986) and Largent et al. (1977). To determine the names and color codes we used Kornerup \& Wanscher (1978).

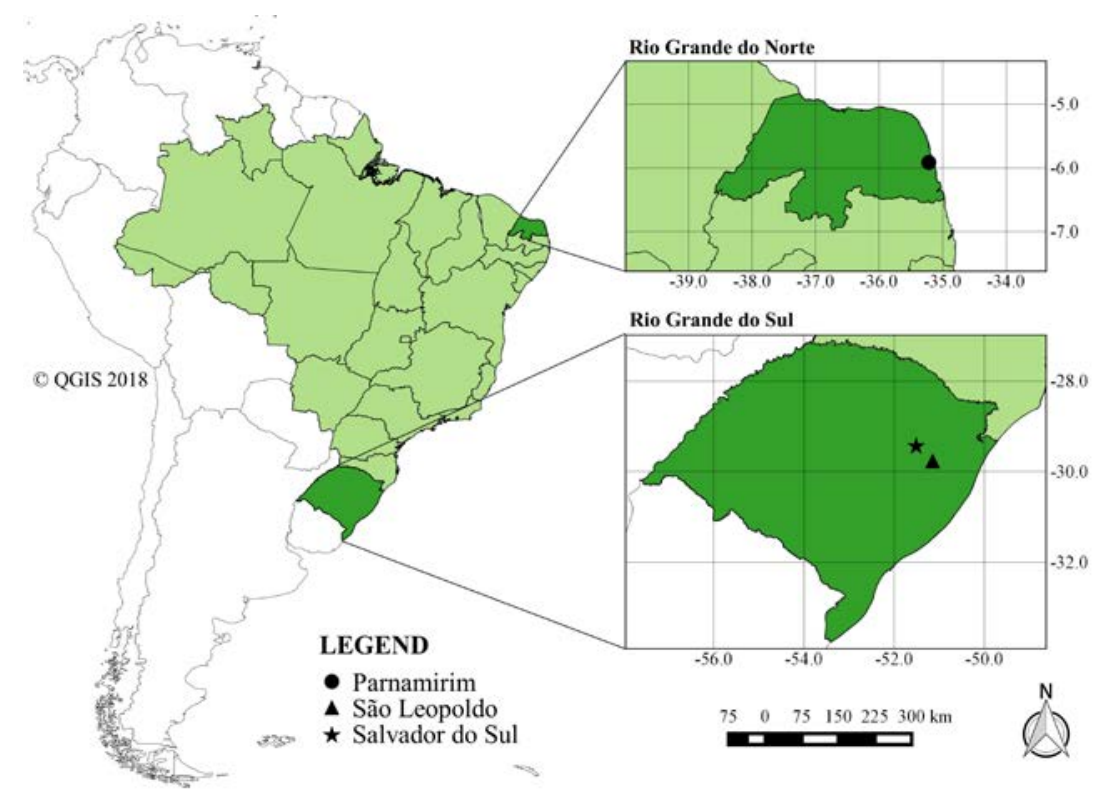

Fig. 1 - Map showing the collection site of the new report to Rio Grande do Norte, Parnamirim, collected in 2015, and the two collections of Rick to Rio Grande do Sul, São Leopoldo, collected in 1929 and Salvador do Sul, collected in 1944.

The length $\times$ width in face-view $\times$ width in side-view of basidiospores were measured; the length of the basidia were measured excluding sterigmata. The value of $\mathrm{Q}$ was calculated as the quotient between the length and width, ' $Q m$ ' is the value averaged from ' $Q$ ' and ' $n$ ' is the number of measured basidiospores/number of analyzed basidiomata/number of collections (Bas 1969). 
Specimens were deposited at the Fungal Collection of the Universidade Federal do Rio Grande do Norte (UFRN-Fungos). Identification was made through keys proposed for the genus (Ola'h 1969, Watling \& Gregory 1987, Young 1989, Gerhardt 1996) and by comparison with Rick materials loaned by the herbarium PACA (Thiers continuously updated). Generic taxonomical concepts followed Gerhardt (1996).

\section{Results}

Panaeolus acuminatus (P. Kumm.) Quél., Mém. Soc. Émul. Montbéliard 5: 257 (1872). Figs 2-3 三Agaricus acuminatus Schaeff. Fung. Bavar. Palat. nasc. 4: 44, t. 202 (1774).

Facesoffungi Number: FoF 05841

Pileus 13-15 mm diam., conic-campanulate, with a prominent rounded apex, surface smooth, dry, hygrophanous, margin slightly crenate, brownish-beige (6E3) to light brown (6D5). Lamellae adnexed, ventricose, brownish grey (5F2) with darker spots, crowded, narrow, lamellulae not observed. Stipe 20-70 × 1.8-2 mm, central, equal, cylindrical, fistulose, surface slightly longitudinally-striated, consistency cartilaginous, ranging from brown (5C4) to brownish orange (5B6). Context thin $(<1 \mathrm{~mm})$, pale yellow (4A3). Veil absent. Spore print dark grey brown (1F1).

Basidiospores 11.5-14.5 × 5.5-9.5 × 5.5-8 $\mu \mathrm{m}$, (average $=12.6 \times 8.6 \times 7.3 \mu \mathrm{m}, \mathrm{Q}=1.2-$ 1.7, $\mathrm{Qm}=1.4, \mathrm{n}=30 / 2 / 2$ ), limoniform to sublimoniform, rhomboid in face view, ellipsoid in sideview, smooth, thick-walled (0.6-1.4 $\mu \mathrm{m})$, strongly flattened, apically truncate by a central germpore, dark brown in $\mathrm{KOH}$ (Figs 2c, 3d). Basidia 15-20.5 × 8-11.5 $\mu \mathrm{m}$, broadly clavate to cylindric-clavate, 1-2-4 spored, predominantly 2-spored, hyaline (Fig. 3e). Pleurocystidia absent. Lamellae edge sterile. Cheilocystidia 24.5-33.1 × 7-8 $\mu \mathrm{m}$, slender, slightly lageniform, slightly flexuous, abundant, thin walled, hyaline. Lamellae trama regular with filamentous to inflated hyphae 6.5-14.5 $\mu \mathrm{m}$ diam., thin-walled, hyaline. Subhymenium cellular composed by isodiametric cells 3-7.5 $\times 3-7 \mu \mathrm{m}$, thin-walled, hyaline, light brown. Pileipellis an epithelium composed by isodiametric to broadly clavate cells, $11.5-43 \times 11.5-37.5$, thin walled, hyaline (Fig. 3b). Pileocystidia 10.5-35.5 × 5.5-8.5, cylindrical to slightly lageniform, sometimes with subcapitate apex, scattered, thin-walled, predominately brownish, sometimes hyaline. Hypodermium a layer of interwoven, filamentous hyphae, 1.5-4.5 $\mu \mathrm{m}$ diam., anticlinal, smooth, thin-walled, light brown. Pileus trama composed by interwoven hyphae 5.5-16.5 $\mu \mathrm{m}$ diam., anticlinal, thin walled hyaline. Stipitipellis a cutis, composed of filamentous hyphae 1.5-6 $\mu \mathrm{m}$ diam., smooth, hyaline. Stipe trama regular, with longitudinally oriented hyphae 4.5-12.5 $\mu \mathrm{m}$ diam., smooth, hyaline. Caulocystidia 18.5-39 × 3.5-12 $\mu \mathrm{m}$, lageniform, slender, slightly flexuous, frequent to abundant, thin walled, hyaline. (Fig. 3a). Clamp connections absent in all tissues examined.

Habitat - Scattered to gregarious, in a lawn without herbivorous dung, and on sandy soil in a sheltered location near urban area.

Distribution - Worldwide: Africa (Pegler 1977), Asia (Vrinda et al. 1999), Europe (Watling \& Gregory 1987, Gerhardt 1996), North America (Morgan 1907), South America (Rick 1930, Niveiro \& Albertó 2012), and Australia (Cleland 1934).

Material examined - Brazil, Rio Grande do Norte, Parnamirim, Parque das Árvores, on grassland, 24 April 2015, M.D. Xavier MDX-001, (UFRN-Fungos 3072).

Additional material examined - Panaeolus acuminatus: Brazil, Rio Grande do Sul, Salvador do Sul, São Salvador, 19 January 1944, J. Rick s/n (PACA 20917); and São Leopoldo collected in 1929, J. Rick s/n (PACA 14494); Panaeolus rickenii: Brazil, Mato Grosso do sul, Maracaju Mountains, Corguinho, 12 November 2014, A.K.M. Oliveira et. al. (SP466286). 

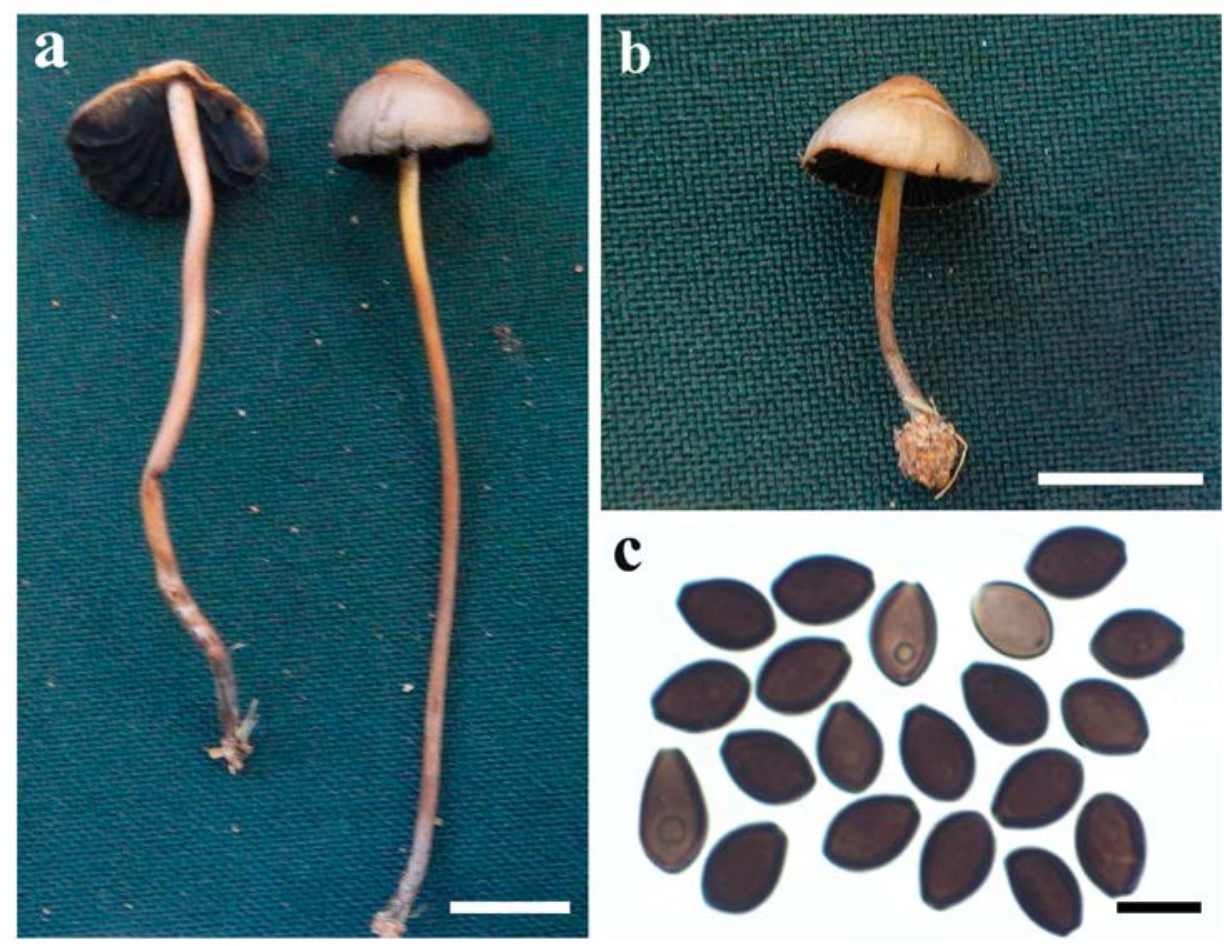

Fig. 2 - Panaeolus acuminatus (UFRN-Fungos 3072): a-b Basidiomata. c Basidiospores. Scale bars: $\mathrm{a}-\mathrm{b}=10 \mathrm{~mm}, \mathrm{c}=10 \mu \mathrm{m}$.

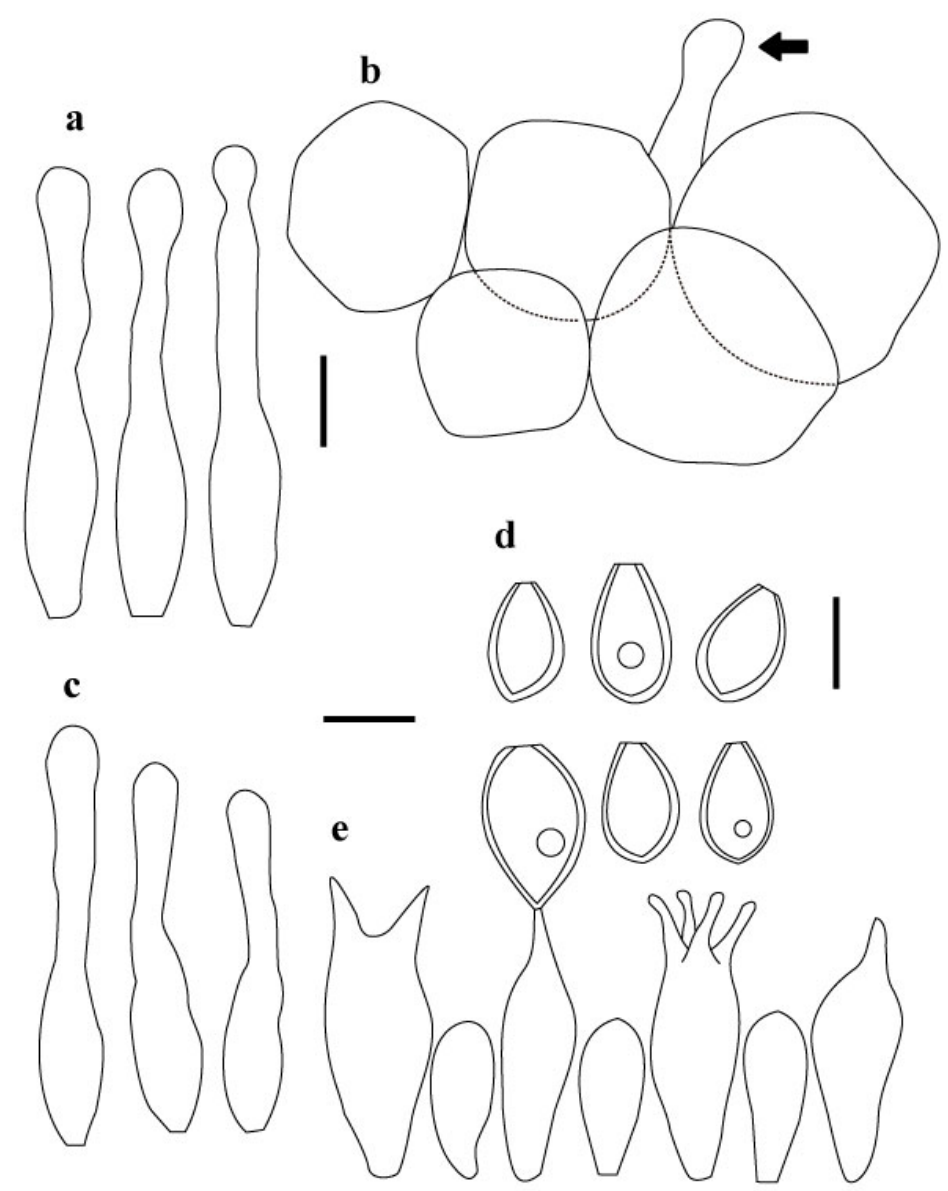

Fig. 3 - Panaeolus acuminatus (UFRN-Fungos 3072): a Cheilocystidia. b Pileipellis showing the epithelium structure with one pileocystidium indicated with an arrow. c Caulocystidia. $\mathrm{d}$ Basidiospores. e Basidia and basidioles. Scale bars: a-e $=10 \mu \mathrm{m}$. 


\section{Discussion}

Panaeolus acuminatus was originally described by Schaeffer (1774) as Agaricus acuminatus. However, there are no exsiccates associated with the name, leaving only the Schaeffer's illustration as a lectotype (Gerhardt 1996). The species has many synonyms. It was also named as Coprinarius acuminatus (Quél.) Quél., Stropharia acuminata (Scop.) Murrill. and Agaricus carbonarius Batsch. Other authors described the same species under other names, all also synonyms. Junghuhn described in 1830 A. caliginosus Jungh., in which was interpreted later as $P$. caliginosus (Jungh.) by Gillet (1878). In addition, the epithet caliginosus was recombined to Chalymmota caliginosa (Jungh.) P. Karst. and Coprinarius caliginosus (Jungh.) Quél. in 1879 and 1886 respectively. They also are synonyms of $P$. acuminatus. Unfortunately the material described by Junghuhn has not been found so far (Gerhardt 1996). Gerhardt (1996) reviewed many specimens belonging to this species and proposed an epitype (Gerhardt 83049) for $P$. acuminatus, deposited in Botanisches Museum Berlin.

Our specimens agree with in many aspects the descriptions provided by Gerhardt (1996) due its acuminate, very pointed or rounded pileus, hygrophanous pileus surface, dark-brown flattened basidiospores, absence of pleurocystidia and slender cheilocystidia (Gerhardt 1996). We also compared our description with the ones performed by Watling \& Gregory (1987) and Gerhardt (1996) as shown in the Table 1.

Table 1 Morphologic comparison among Brazilian collection of P. acuminatus, Gerhardt (1996) and Watling \& Gregory (1987).

\begin{tabular}{|c|c|c|c|}
\hline & This study & Gerhardt (1996) & Watling \& Gregory (1987) \\
\hline Pileus size & $13-15 \mathrm{~mm}$ & $10-40 \mathrm{~mm}$ & $20-40 \mathrm{~mm}$ \\
\hline Pileus shape & $\begin{array}{l}\text { Conic-campanulate, with } \\
\text { a rounded apex }\end{array}$ & $\begin{array}{l}\text { Convex, with } \\
\text { pronounced pointed to } \\
\text { rounded apex }\end{array}$ & $\begin{array}{l}\text { Never parabolic, with pointed } \\
\text { or rounded apex }\end{array}$ \\
\hline Stipe size & $20-70 \times 1.8-2 \mathrm{~mm}$ & $30-25 \times 1.5-3 \mathrm{~mm}$ & $35-50 \times 2-3 \mathrm{~mm}$ \\
\hline Basidiospore size & $\begin{array}{l}11.5-14.5 \times 5.5-9.5 \times \\
5.5-8 \mu \mathrm{m}\end{array}$ & $\begin{array}{l}13-15 \times 9-11 \times 7-8 \\
\mu \mathrm{m}\end{array}$ & $12-15 \times 9-11 \times 7-9 \mu \mathrm{m}$ \\
\hline $\begin{array}{l}\text { Number of } \\
\text { sterigmata }\end{array}$ & mostly 2 & 2 and 4 & 4 \\
\hline Basidia size & $15-20.5 \times 8-11.5 \mu \mathrm{m}$ & $25-30 \times 10-13 \mu \mathrm{m}$ & $27.5-35(-40) \times 8.5-12.5 \mu \mathrm{m}$ \\
\hline Cheilocystidia size & $24.5-33.1 \times 7-8 \mu \mathrm{m}$ & Not informed & $25-35 \times 8.5-12.5 \mu \mathrm{m}$ \\
\hline $\begin{array}{l}\text { Cheilocystidia } \\
\text { shape }\end{array}$ & $\begin{array}{l}\text { Slightly lageniform, } \\
\text { slightly flexuous }\end{array}$ & Slightly lageniform & $\begin{array}{l}\text { Filiform-cylindric, slightly } \\
\text { swollen towards the apex }\end{array}$ \\
\hline
\end{tabular}

Furthermore, we examined two Rick's collections, PACA 20917 and PACA 14494. The tissues did not rehydrate satisfactorily. However, the identification of the species was confirmed from the characteristics of the basidiospores [limoniform to sublimoniform, rhomboid in face view, ellipsoid in side-view, smooth, thick-walled $(0.6-1.4 \mu \mathrm{m})$, strongly flattened, apically truncate by a central germ-pore; basidiospores size; 10.5-15 $(-15.5) \times 5-9 \times 6.5-11 \mu \mathrm{m}]$, and the chemical reaction, on which they do not discolor in sulphuric acid.

According to Gerhardt (1996), P. acuminatus belongs to subgen. Panaeolus sect. Laevispora sensu Gerhardt (1996), due to dry, hygrophanous pileus, lack of veil remnants, smooth basidiospores, absence of metuloids and cheilocystidia with yellowish droplets or content. Among the species of the sect., $P$. bernicis A.M. Young, $P$. fimicola (Pers.) Gillet and P. microsporus Ola'h \& Cailleux have sulphidia (Gerhardt 1996). Panaeolus fraxinophilus A.H. Sm. is a lignicolous species that grows on Fraxinus sp. (Gerhardt 1996). Panaeolus alcidis M.M. Moser and $P$. subfirmus P. Karst have larger basidiospores, measuring 16-18 $\times 11-12.5 \times 8.5-10 \mu \mathrm{m}$ and 16-20 × 10-11 × 9-10 $\mu \mathrm{m}$ respectively, while P. reticulatus Overh. has smaller ones 8.5-11 $\times$ 6.5-8 × 5-6 $\mu \mathrm{m}$ (Gerhardt 1996). Panaeolus cinctulus (Bolton) Sacc. resembles only the flattened 
spores (7-8 $\mu \mathrm{m}$ in side view), but it is easily distinguished by having much fleshier basidiomes and larger and broader often capitaded cheilocystidia 30-50 × 8-12 $\mu \mathrm{m}$ (Gerhardt 1996). Panaeolus paludosus Cleland is the most similar species, in which also shares the dark, hygrophanous and campanulate pileus tending to be hemispherical to convex, without veil remnants. However, $P$. paludosus has rhomboid transparent basidiospores (11.4-14 × 9-10 × 6-7 $\mu \mathrm{m})$ and more bulbous cheilocystidia 25-40 × 7-10 $\mu \mathrm{m}$ (Gerhardt 1996).

Panaeolus rickenii is other similar species distinguished by Hora (1960) based in collections with capitate-clavate cheilocystidia. This species was described as a variety of P. acuminatus by Gerhardt (1996), although Watling \& Gregory (1987) considered as an autonomous taxon. More recently, P. rickenni was reported from Mato Grosso do Sul by Bononi et al. (2017), and we checked its exsiccate SP 466286. The Brazilian collection of $P$. rickenii has larger $20-30 \mathrm{~mm}$ and non-acuminated pileus (see the picture in Bononi et al. 2017: 364), light brown to brown basidiospores, basidia predominantly with four sterigmata, and sphaeropenduculate to ventricosefusoid then cylindrical with mucronated apex cheilocystidia (20-34 × 9-14 $\mu \mathrm{m})$. On the other hand, our collections of P.acuminatus presents smaller (13-15 mm diam.) and slightly acuminated pileus, brown basidiospores, basidia predominantly bi-spored and lageniform thin-walled cheilocystidia 24.5-33.1 × 7-8 $\mu \mathrm{m}$.

There are two records of $P$. acuminatus in South America: one from Argentina and another from the subtropical region of and Brazil (Rick 1930, Niveiro \& Albertó 2012). Now we recorded for the first time Northeast of Brazil, proving that in South America, this species is not restricted to subtropical regions. In addition, $P$. acuminatus and its related species, probably form a speciescomplex that need a molecular and phylogenic analysis for understand the positioning of the species and the validity of some of the names used in their taxonomy.

\section{Acknowledgements}

The authors would like to express their thanks to Dra. Maria Salete Marchioretto from PACA herbarium and Adriana de Mello Gugliotta from SP herbarium for loan of the specimens, CNPq (Brazilian National Council for Scientific and Technological Development) for the scientific initiation scholarship and CAPES-(Coordenação de Aperfeiçoamento de Pessoal de Nível Superior) for the PhD scholarship awarded to Alexandre G. S. Silva-Filho.

\section{References}

Alves MH, Cavalcanti MA. 1996 - Coprinaceae en el campus de la Universidad Federal de Pernambuco, Recife, PE, Brasil. Bol. Micol. 11, 33-40.

Bas C. 1969 - Morphology and subdivision of Amanita and a monograph of its section Lepidella. Persoonia Molecular Phylogeny and Evolution of Fungi 5(4), 285-573.

Bononi VLR, Oliveira AKMD, Gugliotta ADM, Quevedo JRD. 2017 - Agaricomycetes (Basidiomycota, Fungi) diversity in a protected area in the Maracaju Mountains, in the Brazilian central region. Hoehnea 44(3), 361-377.

Cleland JB. 1934 - Toadstools and mushrooms and other large fungi of South Australia. Part I. 1, 147.

De Meijer AAR. 2001 - Mycological work in the Brazilian state of Paraná. Nov. Hedw. 72, 105159.

De Meijer AAR. 2006 - A preliminary list of the macromycetes from the Brazilian State of Paraná. Bol. Mus. Bot. Munic. 68, 1-55.

Gerhardt E. 1996 - Taxonomische Revision der Gattungen Panaeolus and-Panaeolina (Fungi, Agaricales, Coprinaceae). Bibliot. Bot. 147, 1-150.

Gillet CC. 1878 - Les Hyménomycètes ou Description de tous les Champignons qui Croissent en France. C. Thomas, 621-623

Hora FB. 1960 - New check list of British agarics and boleti: Part IV. Validations, new species and critical notes. Transactions of the British Mycological Society, 43(2), 440-459. 
Kornerup A, Wanscher JH. 1978 - Methuen handbook of colour. 3rd edn London: Eyre Methuen. $1-252$.

Largent DL. 1986 - How to Identify Mushrooms to Genus I: Macroscopic Features. Eureka: Mad River Press. 1-166.

Largent DL, Johnson D, Watling R. 1977. How to Identify Mushrooms to Genus III: Microscopic Features. Eureka: Mad River Press. 1-148.

Maia LC, Carvalho Júnior AA, Cavalcanti LH, Gugliotta AM et al. 2015 - Diversity of Brazilian fungi. Rodriguésia 66(4), 1033-1045.

Melo RFR, Chikowski RDS, Miller AN, Maia LC. 2016 - Coprophilous Agaricales (Agaricomycetes, Basidiomycota) from Brazil. Phytotaxa 266(1), 1-14.

Morgan AP. 1907 - North American Species of Agaricaceae. The Melanosporae. The Journal of Mycology 13(2), 53-62.

Niveiro N, Albertó EO. 2012 - Checklist of the Argentine Agaricales 2. Coprinaceae and Strophariaceae. Mycotaxon 120, 505.

Ola'h GM. 1969 - Le genre Panaeolus: essai taxinomique et physiologique. Laboratoire de cryptogamie du Muséum national d'histoire naturelle 10. 1-273.

Pegler DN. 1977 - A preliminary agaric flora of East Africa. Her Majesty's Stationery Office. 410-412.

Rick J. 1930 - Contributio IV ad monographiam agaricearum Brasiliensium. Broteria 24, 97-118.

Rick AGS, Seger C, Cortez VG. 2018 - The neurotropic genus Copelandia (Basidiomycota) in western Paraná State, Brazil. Revista Mex. Biodivers. 89(1), 15-21.

Schaeffer JCG. 1774 - Fungorum qui in Bavaria et Palatinatu circa Ratisbonam nascuntur icones: Nativis Coloribvs Expressae. Zunkel. 4, 1-136.

Silva-Filho AGS, Seger C, Cortez VG. 2019 - Panaeolus (Agaricales) from western Paraná state, south Brazil, with a description of a new species, Panaeolus Sylvaticus. Edinb. J. Bot. 77, 113.

Singer R. 1986 - The Agaricales in modern taxonomy. 4th ed. Koenigstein, Germany: Koeltz Scientific Books. 533-540.

Sobestiansky G. 2005 - Contribution to a macromycete survey of the States of Rio Grande do Sul and Santa Catarina in Brazil. Brazilian Archives of Biology and Technology 48(3), 437457.

Stijve T, De Meijer AAR. 1993 - Macromycetes from the State of Parana, Brazil, 4.

Thiers B. [continuously updated] - Index Herbariorum: A global directory of public herbaria and associated staff. - New York Botanical Garden's Virtual Herbarium. http://sweetgum.nybg.org/ih/ (accessed 27 June 2018).

Tóth A, Hausknecht A, Krisai-Greilhuber I, Papp T et al. 2013 -Iteratively refined guide trees help improving alignment and phylogenetic inference in the mushroom family Bolbitiaceae. PLoS One, 8(2), e56143.

Vrinda KB, Pradeep CK, Mathew S, Abraham TK. 1999 - Agaricales from Western Ghats-VI. Indian Phytopathology 52(2), 198-200.

Wartchow F, Carvalho AS, Sousa MCA. 2010 - First record of the psychotropic mushroom Copelandia cyanescens (Agaricales) from Pernambuco State, Northeast Brazil. Revista Brasileira de Biociências, 8(1). 59-60.

Watling R, Gregory NM. 1987 - British Fungus Flora. Agarics and Boleti. 5. Strophariaceae \& Coprinaceae pp. Hypholoma, Melanotus, Psilocybe, Stropharia, Lacrymaria \& Panaeolus. 76-93.

Young AM. 1989 - The Panaeoloideae (Fungi, Basidiomycetes) of Australia. Australian systematic botany 2(1), 75-97. 